\title{
Çocuklarda COVID-19 ve Karaciğer
}

\author{
COVID-19 and Liver Relation in Children
}

\author{
DAnna Carina Ergani ${ }^{1}$, Reyhan Gümüştekin', Meltem Gümüş ${ }^{1}$, \\ DHalil Haldun Emiroğlu' ${ }^{1}$
}

'Selçuk Üniversitesi Tıp Fakültesi Çocuk Gastroenterolojisi Bilim Dalı, Konya, Türkiye

\section{ÖZ}

SARS-CoV-2'nin neden olduğu koronavirüs hastalığı 2019 (COVID-19) salgını, dünya çapında önemli bir sağlık ve ekonomik sorun olmaya devam etmektedir. Çocuklarda enfeksiyonun karaciğeri nasıl etkilediğine ve kronik karaciğer hastalığının enfeksiyona yakalanma risk faktörü olmasına ilişkin bilgiler henüz yeterli düzeyde değildir. COVID-19 için farklı tedaviler incelenmektedir ve bunlardan bazıları hepatotoksisite ile ilişkilendirilmiştir. Dünya çapında artan hasta sayısı nedeniyle, ağır hastalık riski olassılığının artabileceği düşünülerek kronik karaciğer hastalığı olanları Covid-19 enfeksiyonundan korumak için yeni yaklaşımlar geliştirilmeye başlanmıştır. Bu amaçla kronik karaciğer hastalığı olanlar için COVID-19 özel bir rehberi de yayınlamıştır.

Anahtar Kelimeler: SARS-CoV-2, pediatrik COVID-19, gastroenteroloji

\section{GíRiş}

SARS-CoV-2 solunum yollarını tutan birçok virüs türü insandan insana solunum damlacıkları (konuşma, hapşırma veya öksürme) yoluyla iletilebildiği gibi, asılı damlacık çekirdekleri ve kontamine yüzeye dokunma sonrası gözler, burun ve ağız mukozası yoluyla da bulaşabilmektedir (1, 2). Koronavirüs hastalığı 2019 (COVID-19) enfeksiyonunda 3 evreden bahsedilmektedir; evre I erken enfeksiyon fazı, evre II pulmoner faz ve evre III hiperinflamasyon fazından oluşmaktadır (3). En sık ateş ve öksürük gibi akciğer tutulumu semptomları görülse de, SARS-CoV-2 gastrointestinal sistemi de içeren sistemik ve

\section{ABSTRACT}

The coronavirus disease 2019 (COVID-19) pandemic caused by SARS-CoV-2 continues to be a major health and economic problem worldwide. There is not enough information about how the infection affects the liver in children and chronic liver disease is a risk factor for this infection. Different treatments are being studied for COVID-19, some of which have been linked to hepatotoxicity. Due to the increasing number of patients worldwide, new approaches have been developed to protect those with chronic liver disease from SARS-CoV-2 infection, considering that the risk of severe disease may increase. For this purpose, COVID-19 has also published a special guide for those with chronic liver disease.

Keywords: SARS-CoV-2, pediatric COVID-19, gastroenterology

multiorgan tutulumlu bir tabloya yol açabilir. Karaciğer, akciğerden sonra ikinci sık tutulan organdır (4).

Buyazıda, COVID-19'un karaciğerinasıletkileyebileceğine, ilişkin güncel verilerin gözden geçirilmesi amaçlanmıştır.

\section{ÇOCUK HASTALARDA YÜKSELMIŞ KARACIĞER TESTLERI VE COVID-19}

Koronavirüs hastalığı 2019 semptomları ile başvuran hastaların bir kısmında serum transaminaz enzim değerlerinde yükseklik görülebilmektedir. Yüksek alanin aminotransferaz (ALT) ve aspartat aminotransferaz 
(AST) seviyeleri hastaların \%16-53'ünde bildirilmiştir (5). Çin'de COVID-19'lu hastaları kapsayan büyük bir seride, hastaların \% 76,3'ünde karaciğer testlerinde (AST, ALT, total bilirubin, gama-glutamil transferaz (GGT) yükseklik saptandığı ve bu yüksekliğin hastaların \% 21,5'unda hastanede yatarken, özellikle ilk iki haftasında ortaya çıktığı bildirilmiştir. Başka bir çalışmada ise, hastaneye yatışta hepatoselüler veya miks tipte karaciğer hasarını düşündüren biyokimyasal bulguları olan hastaların, hastanede yatışları sırasında ciddi hastalığa ilerleme riski daha yüksek bulunmuştur (6).

Çoğu çalışmada, karaciğer disfonksiyonunun hafif ve geçici olduğu, klinik anlamının bulunmadığı ve COVID-19 enfeksiyonunun seyri üzerinde etkisinin olmadığı bildirilmiştir (7). Serum transaminaz enzimlerinin düzeylerindeki yükselme ayrıca ilaç hepatotoksisitesi, sitokin fırtınası ve/veya pnömoni ile ilişkili hipoksi ile de açıklanmıştır (8). Özellikle hastaneye yatış sırasında bazı ilaçlara bağlı oluşabilecek hepatotoksisite yönünden dikkatli bir izlem gerekmektedir (9). Henüz bu konuda çocuk yaş grubu hastalarda yapılmış bir çalışma olmadığı için karaciğer disfonksiyon oranı tam olarak bilinmemektedir.

Birçok çalışmanın sonuçları, AST'nin ALT'den daha sık yükseldiğini göstermektedir. Koronavirüs hastalığı 2019'lu hastalarda alkalen fosfataz ve bilirubin düzeylerinde artış görülmesi seyrektir (10). Bazı hasta serilerinde yüksek AST düzeyleri ile mortalite riski arasında güçlü bir ilişki bulunduğu bildirilmiştir (11). Wuhan'da yapılan çalışmalarda, AST seviyelerinin hastaların \% 24- \% 37'sinde arttığı görülmüş olup bu oran Çin'in diğer bölgelerinden (Zhejiang) daha yüksektir. Vaka serilerinin yayınlandığı 6 çalışmada, AST değerindeki artış prevalansının erkeklerde kadınlardan daha yüksek olduğu gösterilmiştir (12). Bir çalışmada da 552 hastaneden 1099 hastayı içeren geniş bir kohortta ağır hastalığı olmayan 112 hastada $(\%$ 18,2) ve ağır hastalığı olan 56 hastada $(\%$ 39,4) yüksek AST düzeyleri saptanmıştır. Ayrıca, ağır hastalığı olanlardaki yüksek ALT oranı (\% 28.1), hafif hastalığı olanlara (\% 19.8) göre daha yüksek bulunmuştur (5). Başka bir çalışmada ise hastaların yaklaşık \% 50'sinde GGT düzeylerinde yükseklik saptanmıştır (10).

Bir meta-analizde COVID-19'lu hastalarda yüksek serum AST düzeylerinin 2.514 hastanın\% 15'inde, yüksek serum ALT düzeylerinin 2711 hastanın \% 15'inde ve yüksek bilirubin seviyelerinin ise 1.841 hastanın\% 17'sinde rapor edildiğini göstermiştir (13). Ağır derecede akut karaciğer hasarı geliştiği bildirilen olgular seyrek olarak tanımlanmıştır. Çalışmalar COVID-19 ile ilişkili karaciğer etkilenmelerinin çoğunlukla geçici ve hafif derecede olduğunu, klinik önemlerinin bulunmadığını savunmakta 19 ve özel bir tedavi gerekmeksizin yakın takip önermektedir. (14).
SARS - CoV - 2 enfeksiyonu ile enfekte çocukların, yetişkinlere göre daha hafif bir hastalık seyri ve daha iyi bir prognoza sahip olduğu bilinmektedir (15). Qiu ve arkadaşları, Zhejiang'daki üç hastanede COVID-19 olan 36 çocuk hastadan (0-16 yaş) sadece 2 çocukta karaciğer enzimlerinde yükselme saptandığını bildirmiştir (16). Başka bir çalışmada COVID-19 pnömonisi olan annelerden doğan 10 çocuk arasından sadece iki hastada karaciğer enzimlerinde yükseklik saptanmıştır (17). COVID-19'lu çocuklarda ALT ve AST düzeylerinde seyrek olarak hafif artış dışında çoğunlukla normal bulunması nedeni ile Amerikan Karaciğer Hastalıkları Araştırmaları Derneği (AASLD), karaciğer enzimlerinde yükseklik saptanan tüm çocukların altta yatan karaciğer hastalıkları açısından değerlendirilmesini önermektedir (18).

\section{Hepatolojik Hastalık Mekanizması}

SARS-CoV-2, "anjiyotensin dönüştürücü enzim 2" (ACE-2) reseptörüne bağlanır (14). Hepatositler ve kolanjiyositler, ACE-2 reseptörlerini yüksek oranda eksprese ettiklerinden SARS-CoV-2'nin potansiyel hedefleri arasındadırlar (1, 2). Farklı iki çalışmanın sonuçları hepatositlerin \% 2.6'sında ve kolanjiyositlerin \% 59.7'sinde ACE-2 ekspresyonu bulunduğunu göstermiştir (19). Kuppfer hücrelerinde ise ACE-2 reseptörü yoktur. SARS-CoV-2 ile ilişkili koronavirüs enfeksiyonu olan hastaların karaciğer biyopsi sonuçları, hepatositlerde mitozda artış ve balonlaşma dejenerasyonu geliştiğini ve bu durumun karaciğer hücrelerinin apoptozunu indükleyebileceğini düşündürmektedir. $\mathrm{Xu}$ ve arkadaşlarının çalışmasında, mikrovesiküler steatoz, hafif lobüler ve portal inflamasyon saptanmıştır (20). Zhang ve arkadaşları ise hafif sinüzoidal dilatasyon ve minimal lenfositik infiltrasyon bulunduğunu bildirmişlerdir (21). Hiçbir biyopsi örneğinin histopatolojik incelemesinde intranükleer veya intrasitoplazmik viral inklüzyon cisimciğinin saptanmaması nedeniyle bu değişikliklerin SARS-CoV-2 enfeksiyonuna özgü olmadığı ve hipoksemi veya ilaca bağlı karaciğer hasarından da kaynaklanabileceği düşünülmüştür (14).

Tan ve arkadaşları, SARS-CoV-2'ye özgü protein 7a'nın, karaciğer dahil farklı organların hücre dizilerinde kaspaz bağımlı bir yolla apoptozu indüklediğini ve SARS-CoV2'nin doğrudan karaciğer dokusunu etkileme olasılığını doğruladığı hipotezini ileri sürmüştür (22). Ancak karaciğer enzimlerindeki yüksekliğin çoğunlukla hafif ve geç başlangıçlı semptomların daha ciddi karaciğer hasarı ile ilişkili olduğuna dair hiçbir kanıt bulunamaması nedeni ile bazı yazarlar tarafından bu hipoteze itiraz edilmiştir (23). Epstein - Barr virüsü, sitomegalovirüs, herpes simpleks virüsü, parvovirüs ve adenovirüs gibi mikroorganizmaların yol açtığı bazı sistemik viral enfeksiyonlar, dolaşımdaki sitokinlerin neden olduğu immün aktivasyon ve enflamasyonu yansıtan benzer biyobelirteçlerdeki yükseklik ile ilişkilidir (24). Karaciğer enzimleri yüksek olan hastalarda normal 
karaciğer enzim düzeyleri olanlara göre daha yüksek serum pro-inflamatuar sitokinler ve kemokin düzeyleri bildiren birkaç çalışma mevcuttur. Dolayısıyla bu veriler, karaciğer hasarı ile SARS-CoV-2 enfeksiyonunun neden olduğu enflamatuar yanıtlar arasındaki bir ilişkiye işaret etmektedir. Son olarak, bazı yazarlar, antiviraller, antibiyotikler, geleneksel Çin tıbbı, ateş düşürücüler ve analjezikler gibi birden fazla ilacın kullanımına bağlı karaciğer hasarının da laboratuvar testlerindeki bozukluğa katkıda bulunan olası bir faktör olduğunu öne sürmektedir (14).

\section{Hepatolojik Belirtiler}

Kronik karaciğer hastalığının (KKH) şiddetli hastalık seyri için bir risk faktörü olarak kabul edilip edilmeyeceği henüz bilinmemektedir (14). Karaciğerde doğrudan SARS-CoV-2 virüs kaynaklı sitopatik etkiye bağlı olarak karaciğer hasarı meydana gelebilir. Bu durum sistemik inflamatuar yanıt ve / veya altta yatan bir karaciğer hastalığının aktivasyonu ile sonuçlanabilir. Hepatotropik ve non-hepatotropik viral hepatit etkenleri (hepatit $A, B$ veya $C$ virüsleri, sitomegalovirüs, herpes simpleks virüsü) ve karaciğer enzim düzeylerinde yükselmeye yol açabilen diğer nedenlerde araştırılmalıdır. Hidroksiklorokin/ klorokin, lopinavir/ritonavir, remdesivir, tocilizumab veya azitromisin ile tedavi edilen COVID-19 hastalarında ilaca bağlı toksik hepatit gelişmiş olabileceği unutulmamalıdır (25).

Steroidler veya immunmodülatörler gibi immunsüpresif ilaçlar kullanmakta olan KKH'lı hastalarda COVID-19'un daha ağır bir seyir ilişkili olup olmadığı konusunda henüz yeterli bilgi birikimi bulunmamaktadır. Bir çalışmada immunsüpresif ilaç kullanmakta olan $\mathrm{KKH}^{\prime}$ lı çocukların daha kötü bir COVID-19 hastalık seyrine yatkın olduğunu gösteren yeterli veri olmadığını beyan etmiş̧lerdir. Güncel çalışmalar, ilaçta hiçbir değişikliğin veya immünosupresyonda ilaç dozunu azaltmanın zorunlu olmadığını göstermektedir (26).

\section{ÇOCUKLARDA KRONIK KARACIĞER HASTALIKLARINDA COVID 19}

\section{Alkolik Olmayan Yağlı Karaciğer Hastalığı (Nafld) Veya Steatohepatit (Nash)}

Alkole bağlı olmayan yağlı karaciğer hastalığı (NAFLD) veya steatohepatit (NASH) sıklıkla tip 2 diyabetes mellitus, hipertansiyon ve obeziteye eşlik edip şiddetli bir COVID-19 seyri ile ilişkilidir (27). Çin'de 202 hastayı içeren bir çalışmada, obezite ve NAFLD varlığının, COVID-19 hastalığının daha ağır seyir göstermesi riskinde artış ve hastaneye yatıştan taburcu oluncaya kadar daha yüksek karaciğer enzim düzeyleri ile ilişkili bulunmuştur. Çin'de yapılan bir başka çalışmada 214 hastada metabolik hastalık ilişkili yağlı karaciğer hastalığı ve obezitenin yaş, cinsiyet, sigara, diyabet, hipertansiyon ve dislipidemiyle karşılaştırıldığında COVID-19 hastalığının daha ağır seyretme riskinde artışla ilişkili olduğu gösterilmiştir (8). Ancak COVID-19'un NAFLD'deki etkisini anlamak için daha fazla araştırmaya ihtiyaç vardır (14). Çocuk hastalarımızda son zamanlarda obezite ve buna bağlı NAFLD, NASH sıklığında artış olmakla birlikte NAFLD veya NASH ile COVID 19 ilişkisine yönelik herhangi bir çalışma bulunmamaktadır.

\section{Kronik Hepatit B Enfeksiyonu}

Bir çalışmada, COVID-19 nedeni ile hastanede yatan veya ayakta tedavi gören 1099 hasta incelenmiş ve \% 2.1'inde kronik hepatit B enfeksiyonu saptanmış olup bu hastalardan sadece 1'inde ağır seyir görülmesi kronik hepatit B enfeksiyonunun COVID-19'un seyrini etkilemediğini düşündürmüştür (14). Ancak kronik hepatit B enfeksiyonunun COVID-19'daki etkisine yönelik henüz yeterli bir bilgi birikimi bulunmamaktadır.

\section{Otoimmün Hepatit}

Otoimmün hepatitte SARS-CoV-2 enfeksiyonu deneyimi çok azdır. The European Association for the Study of the Liver (EASL) and the European Society of Clinical Microbiology and Infectious Diseases (ESCMID) otoimmün karaciğer hastalığı olan hastalarda immünosüpresif tedavinin azaltılmasını önermemekte ve azaltmanın yalnızca özel koşullar altında (örneğin ilaca bağlı lenfopeni veya bakteriyel/fungal süperenfeksiyon olan şiddetli COVID-19 durumunda) düşünülmesi gerektiğini vurgulamaktadır (14). Anormal karaciğer hasar testleri durumunda, immünosupresif tedavi alan otoimmün hepatitli hastalarda SARS-CoV-2 enfeksiyonu düşünülmelidir. İmmünsüpresyonun COVID-19 üzerindeki etkileri henüz yeterince bilinmemektedir (25).

\section{Karaciğer Sirozu}

Karaciğer sirozu olan hastalarda enflamatuar yanıt sonucu akut-kronik karaciğer yetmezliği gelişebilir (28). Sirozlu hastalarda SARS-CoV-2 ile enfeksiyonu önlemeye yönelik koruyucu önlemler büyük önem taşımaktadır. Yeni başlayan akut karaciğer yetmezliği veya akut dekompansasyonu olan hastalarda SARS-CoV-2 için test yapılması önerilmektedir (25).

\section{Karaciğer Nakli}

COVID-19'un kuluçka döneminde elektif cerrahi geçiren hastalarda yüksek morbidite ve mortalite (\% 20.5) bildirilmiştir (29). Donörlerin ve alıcıların transplantasyondan önce SARS-CoV-2 için rutin olarak araştırılması önerilmektedir (30). Olası COVID-19 beklentisiyle stabil karaciğer nakil hastalarında immünsüpresif ilaçların azaltılması önerilmemektedir. İnfluenza ve pnömokok aşıları önerilmektedir (31). Karaciğer nakil hastalarında COVID-19 enfeksiyonu ile ilgili klinik veriler henüz çok sınırlıdır (14). 


\section{ÇOCUK HASTALARDA COVID 19 TEDAVISINDE KULLANILAN ILAÇLAR}

\section{Lopinavir / Ritonavir}

İnsan immun yetmezlik virüsü (HIV) tedavisi için onaylanmış bir antiretroviral proteaz inhibitörü olan Lopinavir / ritonavir (14 gün -18 yaş arası kullanımı mevcut ), serum aminotransferaz seviyelerinde geçici ve genellikle asemptomatik yükselmelere neden olabilir (32). COVID-19 hastalarında lopinavir/ ritonavir tedavisine başlanması düşünülürse tedavi öncesi karaciğer testleri yapılmalı, ilerlemiş olgularında kullanılmamalıdır. Özellikle çocuklarda döküntü de görülebilir (26).

\section{Hidroksiklorokin}

Hidroksiklorokin ve klorokin, antimalaryal ajanlardır. Karaciğer enzim düzeylerinde yükseklik ile ilişkilendirilmemiştir ve klinik olarak belirgin akut karaciğer hasarının oldukça seyrekbirnedenidir. Karaciğer yetmezliği olan hastalarda doz ayarlaması gerekli değildir (33). Ancak yine de, COVID-19 tedavisinde etkinliği ve güvenliği belirsiz olduğundan hidroksiklorokin dikkatli kullanılmalıdır (34).

\section{Tocilizumab}

Tocilizumab, IL-6 reseptörünün bir monoklonal antagonistidir (25). Kısa süreli serum aminotransferaz ve bilirubin düzeylerinde yükselmelere neden olabilir (35). Tedaviye başlamadan önce karaciğer testleri ve viral belirteç değerlendirmeleri önerilir. Tocilizumab, serum aminotransferaz seviyeleri üst normal sınırın 1,5 katından daha yüksek olduğunda kontrendikedir. Hepatit B virüsü (HBV) reaktivasyonu, tocilizumab tedavisi sırasında da ortaya çıkabilir. Bu nedenle, tocilizumab alan HBV ile enfekte COVID-19 hastalarında HBV tedavisi başlatılmalıdır (25).

\section{Remdesivir}

Şu anda araştırılmakta olan yeni bir Ribonükleik asit (RNA) polimeraz inhibitörü olarak görev yapan nükleotid analoğudur. Flavivirüsler, Ebola virüsü ve koronavirüslere karşı potansiyel antimikrobiyal etkileri vardır. Geniş spektrumu ve SARS-CoV-2'ye karşı bildirilen in vitro etkinliği nedeniyle, COVID-19 tedavisi için umut verici bir ajan olarak kabul edilir $(36,37)$. Geri dönüşümlü hepatotoksisite ve nefrotoksisite potansiyeline sahiptir ve serum ALT ve AST düzeylerinde artışa neden olabilir (25). Benzer şekilde, bir RNA polimeraz inhibitörü olan Favipiravir hakkında hiçbir veri yoktur (38). Sağlık uzmanlarına, hastaların mevcut antiviral tedavileri ile COVID-19 için kullanılan tedaviler arasındaki etkileşimler için Liverpool Üniversitesi'nin HEP İlaç Etkileşimleri web sitesine ( https://www.hep-druginteractions. org ) başvurmaları önerilmektedir (25).

\section{SONUÇ}

SARS-CoV-2 enfeksiyonu sıklıkla farklı derecelerde anormal karaciğger testleriyle, özellikle de geçici ve hafif derecede yükselmiş serum transaminaz düzeyleri ile ilişkilidir. Bağışıklığı baskılanmış yetişkin veya çocuk kronik karaciğer hastalarında SARS-CoV-2 enfeksiyonu insidansı ile ilgili olarak literatürde henüz yeterli bilgi birikimi bulunmamaktadır. Ancak siroz, NAFLD, otoimmün karaciğer hastalıkları veya karaciğer nakli olan hastalarda COVID-19 riski daha yüksek olabilir (14).

COVID-19 salgını Türkiye'de ve dünyada insanların, hastaların ve sağlık çalışanlarının günlük yaşamlarını olumsuz etkilemiştir. Karaciğer hastalığı olan hastaları, karaciğer nakil alıcılarını ve sağlık çalışanlarını SARSCoV-2 enfeksiyonuna karşı korumak klinisyenlerin ve diğer sağlık personelinin en önemli görevidir. Hiç şüphe yok ki COVID-19 klinik uygulama ve hasta bakımı üzerinde büyük bir etkiye sahiptir. Bugün tüm dikkatler COVID-19'a odaklanmış olsa da, kronik hastalığı olan hastaların bakımı, felaketle sonuçlanabileceği için ihmal edilmemelidir.

\section{ETIK BEYANLAR}

Hakem Değerlendirme Süreci: Harici çift kör hakem değerlendirmesi.

Çıkar Çatışması Durumu:Yazarlar bu çalışmada herhangi bir çıkara dayalı ilişki olmadığını beyan etmişlerdir.

Finansal Destek: Yazarlar bu çalışmada finansal destek almadıklarını beyan etmişlerdir.

Yazar Katkıları: Yazarların tümü; makalenin tasarımına, yürütülmesine, analizine katıldığını ve son sürümünü onayladıklarını beyan etmişlerdir.

\section{KAYNAKLAR}

1. Cevik M, Bamford C, Ho A. COVID-19 Pandemic-a focused review for clinicians. Clinical Microbiology and Infection. 2020 Apr 21.

2. Zhu N, Zhang D, Wang W, et al. A novel coronavirus from patients with pneumonia in China, 2019. New Engl J Med. 2020;382:72733.

3. Siddiqi HK, Mehra MR. COVID-19 illness in native and immunosuppressed states: a clinical-therapeutic staging proposal. The Journal of Heart and Lung Transplantation. 2020

4. Portincasa P, Krawczyk M, Antonia Machill, Lammert F, Di Ciaula A. Hepatic consequences of COVID-19 infection. Lapping or biting?. Eur J Intern Med. 2020 Jul; 77: 18-24.

5. Zhang C, Shi L, Wang FS. Liver injury in COVID-19: management and challenges. Lancet Gastroenterol Hepatol. 2020;5:428-430.

6. Cai Q, Huang D, Yu H, Zhu Z, Xia Z, Su Y. Characteristics of liver tests in COVID-19 patients. J Hepatol. 2020 doi: 10.1016/j. jhep.2020.04.006.

7. Bangash MN, Patel J, Parekh D. COVID-19 and the liver: little cause for concern. Lancet Gastroenterol Hepatol. 2020 doi: 10.1016/ S2468-1253(20)30084-4.

8. Ridruejo E., Soza A. The liver in times of COVID-19: What hepatologists should know. Ann Hepatol. 2020 July-August; 19(4): 353-358.

9. Cai Q, Huang D, Yu H, Zhu Z, Xia Z, Su Y. Characteristics of Liver Tests in COVID-19 Patients. J Hepatol. 2020 
10. Schaefer EAK, Arvind A, Chung RT, et al. Interrelationship Between Coronavirus Infection and Liver Disease. CLINICAL LIVER DISEASE, VOL 15, NO 5, MAY 2020.

11. Lei F, Liu YM, Zhou F, Qin JJ, Zhang P, Zhu L. Longitudina association between markers of liver injury and mortality in COVID-19 in China. Hepatology. 2020

12. Fan $Z$, Chen L, Li J, Cheng X, Jingmao Y, Tian C. Clinical Features of COVID-19-Related Liver Damage. Clin Gastroenterol Hepatol. 2020

13. Sultan $S$, Altayar $O$, Siddique $S M$, et al. AGA institute rapid review of the GI and liver manifestations of COVID-19, meta-analysis of international data, and recommendations for the consultative medicine of patients with COVID-19. Gastroenterology. 2020 May; doi: 10.1053/j.gastro.2020.05.001.

14. Isabel Garrido I, Liberal R, Macedo G. COVID-19 and liver diseasewhat we know on 1st May 2020. Aliment Pharmacol Ther. 2020 Jun 2 : 10.1111/apt.15813.

15. Ludvigsson F. Systematic review of COVID-19 in children shows milder cases and a better prognosis than adults. Acta Paediatr. 2020;109:1088-1095.

16. Qiu H, Wu J, Hong $L$, et al. Clinical and epidemiological features of 36 children with coronavirus disease 2019 (COVID-19) in Zhejiang China: an observational cohort study. Lancet Infect Dis. 2020.

17. Zhu H, Wang L, Fang C, et al. Clinical analysis of 10 neonates born to mothers with 2019-nCoV pneumonia. TransI Pediatr. 2020;9:51-60.

18. American Association for the Study of Liver Diseases. Clinical insights for hepatology and liver transplant providers during the COVID-19 pandemic. https://www.aasld.org/about-aasld/covid19-resources. Accessed April 14, 2020

19. Chai $\mathrm{X}, \mathrm{Hu} L$, Zhang $Y$, et al. Specific ACE2 expression in cholangiocytes may cause liver damage after 2019-nCoV infection. bioRxiv. 2020. 10.1101/2020.02.03.931766

20. Xu Z, Shi L, Wang Y, et al. Pathological findings of COVID-19 associated with acute respiratory distress syndrome. Lancet Respir Med. 2020;8:420-422.

21. Zhang Y, Zheng L, Liu L, Zhao M, Xiao J, Zhao Q. Liver impairment in COVID-19 patients: a retrospective analysis of 115 cases from a single center in Wuhan city, China. Liver Int. 2020. 10.1111/ liv. 14455

22. Tan Y-J, Fielding BC, Goh P-Y, et al. Overexpression of 7a, a protein specifically encoded by the severe acute respiratory syndrome coronavirus, induces apoptosis via a caspase-dependent pathway. J Virol. 2004;78:14043-14047.

23. Bangash N, Patel J, Parekh D. COVID-19 and the liver: little cause for concern. Lancet Gastroenterol Hepatol. 2020;5:529-530.

24. Adams $\mathrm{H}$, Hubscher $\mathrm{G}$. Systemic viral infections and collateral damage in the liver. Am J Pathol. 2006;168:1057-1059.

25. Kabaçam G, Dayangaç M, Üçbilek E, et al. The COVID-19 pandemic: Clinical practice advice for gastroenterologists, hepatologists, and liver transplant specialists. Turk J Gastroenterol. 2020 May; 31(5): 348-355.

26. Rohani P, Badi AS, Moshiri A, Siadat DS. Coronavirus disease 2019 (COVID-19) and pediatric gastroenterology. Gastroenterol Hepatol Bed Bench. 2020 Autumn; 13(4): 351-354.

27. Boettler T, Newsome PN, Mondelli MU, et al. Care of patients with liver disease during the COVID-19 pandemic: EASL-ESCMID position paper. JHEP Rep. 2020;2(3):100113.

28. Strnad $P$, Tacke F, Koch A, Trautwein C. Liver -guardian, modifier and target of sepsis. Nat Rev Gastroenterol Hepatol. 2017;14:55-66.

29. Lei S, Jiang F, SuW, Chen C, Chen J, MeiW. Clinical characteristics and outcomes of patients undergoing surgeries during the incubation period of COVID-19 infection. EClinicalMedicine. 2020;100331 doi: 10.1016/j.eclinm.2020.100331.

30. Boettler T, Newsome PN, Mondelli MU, Maticic M, Cordero $\mathrm{E}$, Cornberg M. Care of patients with liver disease during the COVID-19 pandemic: EASL-ESCMID position paper. JHEP Rep. 2020;2:100113. doi: 10.1016/j.jhepr.2020.100113.

31. Fix OK, Hameed B, Fontana RJ, Kwok RM, McGuire BM, Mulligan DC. Clinical best practice advice for hepatology and liver transplant providers during the COVID-19 pandemic: AASLD expert pane consensus statement. Hepatology. 2020 doi: 10.1002/hep.31281.

32. Sulkowski MS. Drug-induced liver injury associated with antiretroviral therapy that includes HIV-1 protease inhibitors. Clin Infect Dis. 2004;38:S90-S97.

33. Fries JF, Singh G, Lenert L, Furst DE. Aspirin, hydroxychloroquine, and hepatic enzyme abnormalities with methotrexate in rheumatoid arthritis. Arthritis Rheum. 1990;33:1611-1619.
34. Meyerowitz EA, Vannier AGL, Friesen MGN, et al. Rethinking the role of hydroxychloroquine in the treatment of COVID-19. FASEB J. 2020;34:6027-6037.

35. Genovese MC, Kremer JM, van Vollenhoven RF, et al. Transaminase levels and hepatic events during tocilizumab treatment: pooled analysis of long-term clinical trial safety data in rheumatoid arthritis. Arthritis Rheumatol. 2017;69:1751-1761.

36. Sanders JM, Monogue ML, Jodlowski TZ, Cutrell JB. Pharmacologic treatments for Coronavirus disease 2019 (COVID-19). A review. JAMA. Apr 13

37. Grein J, Ohmagari N, Shin D, et al. Compassionate use of remdesivir for patients with severe Covid-19. N Engl J Med. 2020 Apr 10; doi: 10.1056/NEJMoa2007016.

38. Chen C, Huang J, Yin $P$, et al. Favipiravir versus arbidol for COVID- 19: a randomized clinical trial. medRxiv. 2020. 10.1101/2020.03.17.20037432 